\title{
Revitalisation of spoil tips and socio-economic polarisation - a case study of Ruhr
} area (Germany)

\author{
Marta Chmielewska1 ${ }^{1}$, Marius Otto
}

1 Department of Economic Geography, Faculty of Earth Sciences, University of Silesia, Będzińska Str. 28, 41-200 Sosnowiec, Poland ${ }^{2}$ Cultural Geography Work Group, Department of Geography, RWTH Aachen University, Wüllnerstraße 5b, 52062 Aachen, Germany E-mail address (corresponding author): martachmielewska@gazeta.pl

\begin{abstract}
The paper discusses issues about the revitalisation of spoil tips, socio-economic polarisation and social exclusion in the field of municipal recreational activities based on an example of the largest post-industrial region in Europe - the Ruhr area in Germany. Revitalisation of brownfield areas very often leads to the creation of leisure facilities of various types (with a range of entrance fees) and because of this it may mitigate, or exacerbate, the severity of these negative phenomena. In the Ruhr area there are 104 spoil tips of different origins (mine tips, slag heaps, rubbish dumps), sizes and shapes (from conical heaps, through table mountains shaped tips and intentionally shaped for landscape tips, to major tips) and state of preservation. The research has shown that it is possible to use the majority of these spoil tips in the Ruhr area (87 of them) as leisure facilities as they have been changed into green areas, parks, playgrounds, locations for sports activities and tourist attractions after their restoration. Furthermore, they are mostly accessible free of charge and may serve a wide range of people - from locals to visitors, from children to senior citizens etc., regardless of their income. As such they may mitigate the socio-economic polarisation tendencies in the region.
\end{abstract}

KEY WORDS: spoil tips, revitalisation, socio-economic polarisation, Ruhr area, leisure facilities

\section{Introduction}

In an era of growing poverty and widening divisions in society caused by increasing economic in equality some negative phenomena such as social exclusion and socio-economic polarisation are revealed. Socio-economic polarisation can be broadly defined as the widening gap between groups of people in terms of their economic and social circumstances and opportunities (DoRLING \& WOODWARD, 1996). According to SASSEN (1991) it is a result of restructuring the economy, especially the decline in manufacturing and the concurrent growth of the service sector, which leads to changes in the labour market such as an increase in the number of well-paid jobs and lowwage jobs, a reduction in the number of averagewage jobs as well as a parallel growth in unemployment. In addition another factor that enhances this phenomenon is globalisation (MARCUS \& VAN KEMPEN, 2000). Social exclusion is the result of socio-economic polarisation and is revealed through the existence of groups which lose the means to participate in society, for instance in the labour and housing markets, or access to some amenities such as education, recreation or leisure. Socio-economic polarisation may also be seen in spatial terms, due to socio-economic segregation, as illustrated by separate concentrations of the wealthy and poor (GALE, 1996; MUSTRED \& OSTENDORF, 1998).

Socio-economic polarisation is one of the main research topics in social and urban geography in Western Europe and the USA (KNoX \& PINCH, 2000, WĘCŁAWOWICZ, 2007). Processes connected with polarisation (social exclusion and spatial segregation) became clearly visible first in cities in the USA because of a more significant presence of low-wage jobs taken up mainly by groups already marginalised in society (HAMNETT, 1998, MCCARTHY, 1999). In addition, the result of an increased presence of gated communities as well 
as ghettos in the USA is the development of so called partitioned cities (MARCUS \& VAN KEMPEN, 2002). In Europe the discussion about socioeconomic polarisation in urban society became especially heated when unemployment rates grew in the 1980s (FRIEDRICHS \& TRIEMER, 2008, cf. WIEGANDT, 2012) after the 1970s crisis. Another issue is the socio-economic polarisation in the megacities of less developed countries, which has already led to profound social segregation, like in Havana (COLANTONIO \& POTTER, 2006). Strong socio-economic tensions have also been detected within those cities involved with worldwide trade, the global cities (SASSEN, 1991). Finally, these phenomena are particularly visible in regions in transition e.g. former industrial areas where the closing of unprofitable industrial plants result in rising unemployment rates and social fragmentation (see OTTO \& CHMIELEWSKA, 2012, 2014).

The closing of unprofitable industrial plants in post-industrial areas has another consequence of brownfield areas seen in urban spaces which need revitalisation. The term revitalisation refers to a sequence of planned actions, aimed at social and economic recovery of degraded urban spaces. It is a complex, long-lasting and interdisciplinary process which includes comprehensive changes in the spatial, functional, urban, infrastructural, social and environmental structure of the area (KACZMAREK, 2001, LORENS, 2010). Brownfields are a special type of degraded urban space, characterized by a loss of function and exclusion from use, and also a lack of permanent inhabitants. The success of the revitalisation of such areas is dependent on external factors, in particular their spatial accessibility, and internal factors such as the size of the area and the type of building (DOMAŃSKI, 2000). The advantages of brownfield sites are their proximity to the city centre and the transport infrastructure (BEHR ET AL., 2003). However, the presence of environmental pollution, infrastructural barriers and ownership barriers may make them difficult to re-use (JARCZEWSKI, 2010).

Special types of brownfield sites, particularly hard to revitalize, are spoil tips, which have arisen as a result of the accumulation of overburden or other waste rock which was removed during coal and ore mining (mine tips) or as a waste byproduct from foundries or furnaces (slag heaps). These artificial landforms are generally considered to lower the visual qualities of the landscape. For this reason, in the initial phase of industrial restructuring, many of them were liquidated, and their compositional material was used in mines as backfill, for levelling the area or for construction purposes. In time, however, people began to appreciate them as part of their cultural heritage and it has been noted that after suitable reshaping even large tips can complement and enrich the landscape (LAMPARSKA-WIELAND \& WAGA, 2003).

This paper discusses the issues around the revitalisation of spoil tips and their relation to socio-economic polarisation and social exclusion in the field of municipal recreation to which little attention has so far been paid (as these phenomena are commonly discussed in the field of residential segregation or access to the labour market). In this field, social exclusion and polarisation are revealed in an inequality in the access to leisure facilities some of which are really expensive and therefore exclude low-income households which spend a greater part of their income on rent and basic care. In turn the revitalisation of brownfield sites very often leads to the creation of different types leisure facilities (with a range of entrance fees). So some revitalisation projects may mitigate and others may exacerbate the severity of socioeconomic polarisation and social exclusion. In this paper this issue is considered using the example of the largest post-industrial region in Europe - the Ruhr area in Germany. With over fifty years of industrial restructuring, this region has a lot of experience in the redevelopment of brownfield sites. This area has over 100 spoil tips, which are preserved as industrial monuments of the region's past, but which also needed revitalisation. This paper shows the potential of revitalised spoil tips for mitigating socioeconomic polarisation in a region in conjunction with previously implemented redevelopment projects in the Ruhr area. The results presented here are part of wider research on the social consequences of the revitalisation of brownfield sites conducted by the authors.

\section{Study area}

The Ruhr area is located in western Germany in the state of North Rhine-Westphalia. It is the biggest urban agglomeration in the country previously famous for being one of the largest industrial regions in Europe. Its industrial history started in the $14^{\text {th }}$ century when coal was first exploited on the surface, but the greatest development of mining and steel industries took place in the $18^{\text {th }}$ and $19^{\text {th }}$ centuries. This resulted in the development of an industrial landscape, consisting of mine shafts, coking plants, steelworks, factories, as well as mine tips and slag heaps. In the Ruhr area in 1960 there was a crisis of coal surplus, which was followed by a crisis in the steel industry in 1970, which resulted in the restructuring 
of the industries within the region. As a consequence many mines and plants were closed down resulting in the creation of brownfield sites and this was the beginning of the revitalisation of this region. Nowadays the Ruhr area is a postindustrial region with developed services and high-tech industries as well as a postmodern place for tourism, leisure and culture, which are strongly attached to its industrial history (CHMielewsKa \& OTTO, 2013).

In terms of its physical geography, the Ruhr region is situated in the Westphalian Lowland (ZEPP, 2004). The landscape has been heavily transformed by human activities, particularly through industrialization. There are over a 100 spoil tips of different origins throughout the Ruhr area of various, heights, shapes and states of preservation, which may be distinguished into 4 types. The initial phase of industrialization

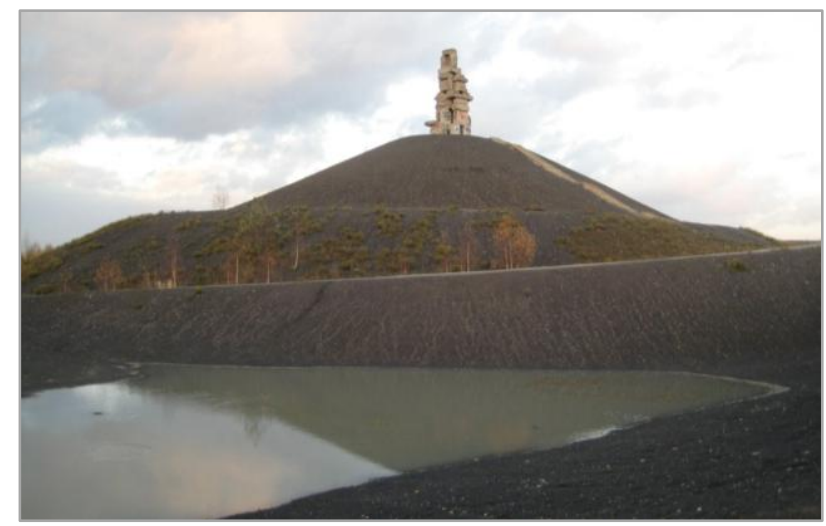

Fig. 1. Rheinelbe mine tip in Gelsenkirchen (M. Chmielewska, 2008)

\section{Materials and methods}

The research was conducted on the basis of data collected during field observations and as a result of a literature review (Tab. 1). Attention was paid to the direction of the revitalisation of particular spoil tips especially their potential use for leisure and recreation and their accessibility (including the entrance fee). The consequences of such redevelopments in terms of their effect on socioeconomic polarisation were then analysed and compared to the relationship with this phenomenon with other revitalisation projects implemented in the region and in other similar regions.

\section{Results}

In the Ruhr area 104 spoil tips were identified, the majority of which were mine tips (92) and in addition 5 rubbish dumps, 4 slag heaps, 1 ground landfill (which arose during the redevelopment of the post-industrial area) and 2 mixed types of tip (Tab. 1). They represent all 4 types of spoil tips resulted in the creation of small conical heaps. The second generation of spoil tips were mounded into in the shape of table mountains. The third form of spoil tips developed in the 1980s, according to the guidelines of the Upper Mining Authority and these were intentionally shaped to prevent them from standing out in stark contrast to the surrounding area, so they have a much larger basal area and have few sharp contours, smooth and round boundary lines and possibly several peaks. The fourth type of spoil tips, are called mayor tips, and occur when two or more formerly independent heaps have grown into one large one (www.ruhrgebiet-industriekultur.de/halden). Due to the flatness of this area these convex anthropogenic landforms are treated like hills and are used for hiking and other recreational activities. Furthermore, as they are clearly visible within the landscape they are often used as landmarks (Fig. 1).

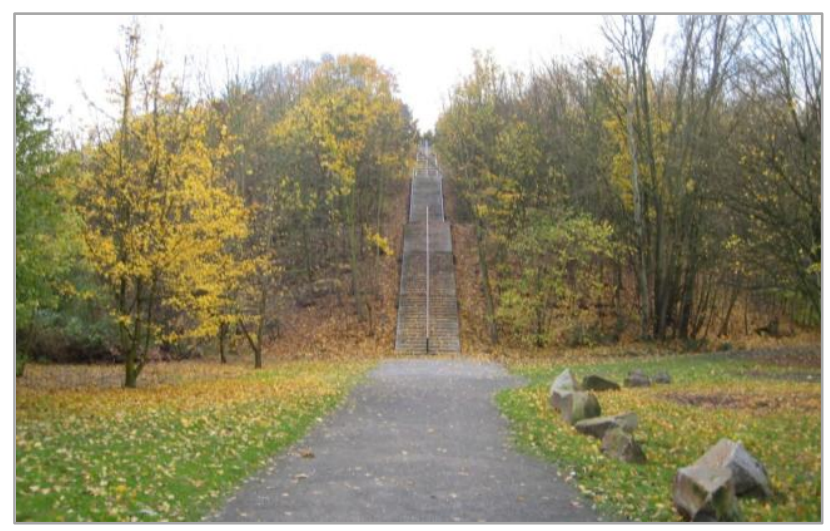

Fig. 2. Steps and footpath on the Schurenbach tip (M. Chmielewska, 2008)

created during the course of history in the Ruhr area - from conical heaps, through table mountain shaped tips and intentionally shaped tips to landscape tips and major tips. Among them there are also totally flattened tips, the smallest of these are lower than $5 \mathrm{~m}$ and their area covers less than 0,5 ha. The highest one is the Oberscholven tip which is $137 \mathrm{~m}$ high. In turn the most extensive is the Hoheward tip with an area of 175 ha. Hoheward tip is also called the biggest one in the area, because it is also quite high $(102 \mathrm{~m})$ and the $3^{\text {rd }}$ tallest in the region (Tab. 1).

Spoil tips are located all over the Ruhr area but especially in a line from Duisburg to Hamm with the highest concentration in the middle of the area. The majority are located in 3 towns: Gelsenkirchen (14), Dortmund (13) and Bochum (10). Others are found in: Gladbeck (8), Lünnen (8), Oberhausen (5), Essen (5), Herne (5), Hamm (5), Bottrop (4), Duisburg (3), Marl (3), Castrop-Rauxel (3), Unna (3), Recklinghausen (3), Berkammen (3) and Witten (3), and some of the other smaller towns (Tab. 1). 
Table 1. The Direction of revitalisation of each spoil tip in the Ruhr area, Germany

(own design on the basis of field studies and: www.ruhrgebiet-industriekultur.de/halden, Berke, 2011; Lange, 2005)

\begin{tabular}{|c|c|c|c|c|c|c|c|c|}
\hline No. & Name of spoil tip & Location & $\begin{array}{l}\text { Height } \\
{[\mathrm{m}]}\end{array}$ & $\begin{array}{l}\text { Area } \\
{[\text { ha] }}\end{array}$ & Origin & Direction of revitalisation & $\begin{array}{l}\text { Leisure } \\
\text { possibility } \\
\text { (yes/no) }\end{array}$ & $\begin{array}{l}\text { Entrance fee } \\
\text { (yes/no) }\end{array}$ \\
\hline 1 & $\begin{array}{l}\text { Halde Alstaden } \\
\text { (Solbadhalde) }\end{array}$ & Oberhausen & 5 & $<1$ & Mine tip & $\begin{array}{l}\text { Greened over and covered with paths. Protected biotope with } \\
\text { pounds. }\end{array}$ & yes & no \\
\hline 2 & Alsumer Berg & Duisburg & 42,2 & 15 & $\begin{array}{l}\text { Rubbish } \\
\text { dump }\end{array}$ & $\begin{array}{l}\text { Greened over and covered with paths. Panorama point on the 'Route } \\
\text { Industriekultur' trail and an element of the theme trail: 'Landmarks } \\
\text { and Panorama Points'. }\end{array}$ & yes & no \\
\hline 3 & Halde Amalia & Bochum & 13 & $?$ & Mine tip & Private property. & no & inaccessible \\
\hline 4 & $\begin{array}{l}\text { Halde Beckstraße } \\
\text { (Tetraeder) }\end{array}$ & Bottrop & 78 & 33 & Mine tip & $\begin{array}{l}\text { Greened over and covered with paths. Landmark -installation in } \\
\text { shape of tetrahedron with viewing platforms. Panorama point on the } \\
\text { 'Route Industriekultur' trail and an element of the theme trail: } \\
\text { 'Landmarks and Panorama Points'. }\end{array}$ & yes & no \\
\hline 5 & Halde Brassert I/II & Marl & $15-18$ & 4,3 & Mine tip & Greened over and covered with paths. A playground at the top. & yes & no \\
\hline 6 & $\begin{array}{l}\text { Halde Brassert III } \\
\text { (Lipper Höhe) }\end{array}$ & Marl & 51 & 34 & Mine tip & Greened over and covered with paths. A viewing point. & yes & no \\
\hline 7 & Halde Brinkfortsheide & Marl & 50 & 168 & Mine tip & Still growing. Inaccessible. & no & inaccessible \\
\hline 8 & Halde Brockenscheidt & Lünen & 15 & 8 & Mine tip & $\begin{array}{l}\text { Greened over and covered with paths. Landmark - a wooden viewing tower. } \\
\text { An element of the theme trail: 'Landmarks and Panorama Points' of } \\
\text { 'Route Industriekultur'. }\end{array}$ & yes & no \\
\hline 9 & Halde Caroline I/II & Bochum & $?$ & $?$ & Mine tip & Currently redeveloped. & no & inaccessible \\
\hline 10 & Halde Caroline & Holzwickede & 8 & $<0,5$ & Mine tip & Greened over and covered with paths. & yes & no \\
\hline 11 & $\begin{array}{l}\text { Halde Consolidation } \\
\text { III/IV/IX }\end{array}$ & Gelsenkirchen & 0 & 0 & Mine tip & Levelled out and changed into a park. & yes & no \\
\hline 12 & $\begin{array}{l}\text { Halde Constantin } \\
\text { IV/V }\end{array}$ & Herne & 6 & 4 & Mine tip & Changed into a park. & yes & no \\
\hline 13 & $\begin{array}{l}\text { Halde Constantin } \\
\text { VIII/IX }\end{array}$ & Bochum & 7 & 4 & Mine tip & Greened over and covered with paths. & yes & no \\
\hline 14 & Deusenberg & Dortmund & 55 & 44 & $\begin{array}{l}\text { Rubbish } \\
\text { dump }\end{array}$ & $\begin{array}{l}\text { Greened over and used as a viewing point and for mountain biking - } \\
\text { facilities: MTB-Arena, rails with ramps or steep curves. }\end{array}$ & yes & no \\
\hline 15 & Halde Dorstfeld I/IV & Dortmund & 19 & 2 & Mine tip & $\begin{array}{l}\text { A cultural monument because of the conical shape. Part of a nature } \\
\text { conservation area. Accessible for walkers. }\end{array}$ & yes & no \\
\hline 16 & $\begin{array}{l}\text { Halde Dorstfeld II/III } \\
\text { (Carlsglück) }\end{array}$ & Dortmund & 10 & 4 & Mine tip & Housing development. & no & no \\
\hline 17 & Halde Eickwinkel & Essen & 21 & 5,3 & Mine tip & Greened over and covered with paths. & yes & no \\
\hline 18 & Halde Ellinghorst & Gladbeck & 5 & 22 & $\begin{array}{l}\text { Mine tip, } \\
\text { rubbish dump }\end{array}$ & $\begin{array}{l}\text { Densely vegetated and a nature conservation area. Accessible for } \\
\text { walkers. }\end{array}$ & yes & no \\
\hline 19 & Emscherhalde & Gelsenkirchen & 20 & 6,5 & Mine tip & Greened over and covered with paths. A part of the Nordsternpark & yes & no \\
\hline
\end{tabular}




\begin{tabular}{|c|c|c|c|c|c|c|c|c|}
\hline & & & & & & Landscape Park. & & \\
\hline 20 & Halde Erin & Castrop-Rauxel & 0 & 0 & Mine tip & Leveled out and change into a park. & yes & no \\
\hline 21 & Halde Eulenbaum & Bochum & 3 & $<0,5$ & Mine tip & $\begin{array}{l}\text { Greened over and covered with paths. An element of the 'History of } \\
\text { Mining' Trail through Bochum. }\end{array}$ & yes & no \\
\hline 22 & $\begin{array}{l}\text { Halde Ewald- } \\
\text { Fortsetzung } \\
\end{array}$ & $\begin{array}{l}\text { Oer- } \\
\text { Erkenschwick }\end{array}$ & 54 & 46 & Mine tip & $\begin{array}{l}\text { Greened over and covered with paths. A'green classroom' - great } \\
\text { stone blocks arranged in a circle. }\end{array}$ & yes & no \\
\hline 23 & $\begin{array}{l}\text { Halde Friederica } \\
\text { (Alter Hellweg) }\end{array}$ & Unna & 6 & $<0,3$ & Mine tip & Private property - grounds of a farm. & no & inaccessible \\
\hline 24 & Halde Friederika & Bochum & 0 & 2 & Mine tip & Levelled out and changed into a park. & yes & no \\
\hline 25 & Halde Frohe Ansicht & Fröndenberg & 8 & $<0,5$ & Mine tip & Forested, accessible but without any infrastructure. & yes & no \\
\hline 26 & $\begin{array}{l}\text { Halde Gen. } \\
\text { Blumenthal I/II/VI }\end{array}$ & Recklinghausen & 12 & 10 & Mine tip & Greened over, partly accessible with paths. & yes & no \\
\hline 27 & $\begin{array}{l}\text { Landschaftsbauwerk } \\
\text { Gneisenau }\end{array}$ & Dortmund & 20 & 8 & $\begin{array}{l}\text { Rubbish } \\
\text { dump }\end{array}$ & Part of a park with a playground. & yes & no \\
\hline 28 & Halde Gotthelf & Dortmund & 43 & 6 & Mine tip & Greened over and covered with paths. & yes & no \\
\hline 29 & Halde Graf Moltke I/II & Gladbeck & 21 & 5 & Mine tip & Part of the 'Braucker Alpen'. Greened over and covered with paths. & yes & no \\
\hline 30 & $\begin{array}{l}\text { Halde Graf Moltke } \\
\text { III/IV }\end{array}$ & Gladbeck & 49 & 20 & Mine tip & Part of the 'Braucker Alpen'. Inaccessible - it is a burning spoil tip. & no & inaccessible \\
\hline 31 & Grevel Alm & Dortmund & 40 & 37 & $\begin{array}{l}\text { Rubbish } \\
\text { dump }\end{array}$ & Greened over and covered with paths. Viewing platforms. & yes & no \\
\hline 32 & Halde Groppenbruch & Dortmund & 17 & 18 & Mine tip & Currently redeveloped, used (illegally) by motocross or quad riders & yes & no \\
\hline 33 & Halde Großes Holz & Bergkamen & 84 & 126 & Mine tip & $\begin{array}{l}\text { Greened over and covered with paths. Panorama point on the trail } \\
\text { 'Route Industriekultur' and an element of the theme trail: 'Landmarks and } \\
\text { Panorama Points'. }\end{array}$ & yes & no \\
\hline 34 & Halde Haniel & $\begin{array}{l}\text { Bottrop, } \\
\text { Oberhausen }\end{array}$ & 128 & 107 & Mine tip & $\begin{array}{l}\text { Greened over, with an amphitheatre and art installation and a } \\
\text { brightly painted railway on the top and stations of the Cross path. } \\
\text { Panorama point on the 'Route Industriekultur' trail and an element } \\
\text { of the theme trail: 'Landmarks and Panorama Points'. }\end{array}$ & yes & no \\
\hline 35 & Halde Hannibal I/II & Bochum & 22 & 5 & Mine tip & Greened over and covered with paths. & yes & no \\
\hline 36 & $\begin{array}{l}\text { Halde Hannover } \\
\text { I/II/V }\end{array}$ & Gelsenkirchen & 26 & 5 & Mine tip & Forested, accessible but without any infrastructure. & yes & no \\
\hline 37 & $\begin{array}{l}\text { Heinrich-Hildebrand- } \\
\text { Höhe }\end{array}$ & Duisburg & 35 & 8 & Slag heap & $\begin{array}{l}\text { Park with an art installation in the shape of a roller coaster called 'Tiger } \\
\& \text { Turtle - Magic Mountain'. Panorama point on the 'Route } \\
\text { Industriekultur' trail and an element of the theme trail: 'Landmarks } \\
\text { and Panorama Points'. }\end{array}$ & yes & no \\
\hline 38 & Halde Haus Aden 2 & Bergkamen & 43 & 25 & Mine tip & Mountain biking trail. & yes & no \\
\hline 39 & $\begin{array}{l}\text { Halde Hibernia- } \\
\text { Dreieck }\end{array}$ & Gelsenkirchen & 6,5 & 23 & Mine tip & Arable and grassland, as well as a horse farm. & no & no \\
\hline 40 & Hiltroper Höhe & Bochum & $?$ & 1,6 & $\begin{array}{l}\text { Rubbish } \\
\text { dump }\end{array}$ & A landmark with helical ramp to a viewing platform. & yes & no \\
\hline
\end{tabular}




\begin{tabular}{|c|c|c|c|c|c|c|c|c|}
\hline 41 & Halde Hoheward & $\begin{array}{l}\text { Herten and } \\
\text { Recklinghausen }\end{array}$ & 102 & 175 & Mine tip & $\begin{array}{l}\text { Greened over and covered with paths. Landscape park with } \\
\text { astronomical installations: horizon observatory and } \\
\text { sundial.Panorama point on the 'Route Industriekultur' trail and an } \\
\text { element of the theme trail: 'Landmarks and Panorama Points'. }\end{array}$ & yes & no \\
\hline 42 & Halde Hoppenbruch & Herten & 69 & 59 & Mine tip & $\begin{array}{l}\text { Greened over and covered with paths. Part of a Landscape Park } \\
\text { Hoheward with sculptures dedicated to the wind and a wind turbine. }\end{array}$ & yes & no \\
\hline 43 & Halde Humbert & Hamm & 37 & 16 & Mine tip & Still growing, inaccessible. & no & inaccessible \\
\hline 44 & Halde Hympendahl & Dortmund & $?$ & 11 & Slag heap & Greened over and covered with paths. & yes & no \\
\hline 45 & Halde Ickern & Castrop-Rauxel & $?$ & 8,5 & Mine tip & $\begin{array}{l}\text { Elongated and changed into noise protection with built-in } \\
\text { amphitheatre. }\end{array}$ & yes & no \\
\hline \multirow[t]{2}{*}{46} & Im Hürfeld & Dorsten & 45 & 90 & Mine tip & Still growing. Inaccessible. & no & inaccessible \\
\hline & Halde Jakob & Dortmund & 12 & $?$ & Mine tip & Greened over and covered with paths. & yes & no \\
\hline 47 & Halde Juno & Witten & $?$ & $?$ & Mine tip & Part of a tourist trail through Mutten Valley. & yes & yes \\
\hline 48 & Halde Kissinger Höhe & Hamm & 55 & 45 & Mine tip & $\begin{array}{l}\text { Hiking area with } 17 \mathrm{~km} \text { of walking trails. Panorama point on the } \\
\text { 'Route Industriekultur' trail and an element of the theme trail: } \\
\text { 'Landmarks and Panorama Points'. }\end{array}$ & yes & no \\
\hline 49 & Knappenhalde & Oberhausen & 60 & $?$ & Mine tip & $\begin{array}{l}\text { Greened over and covered with paths. A viewing tower. A part of } \\
\text { CentrO Oberhausen. An element of the theme trail: 'Landmarks and } \\
\text { Panorama Points' of 'Route Industriekultur'. }\end{array}$ & yes & no \\
\hline \multirow[t]{2}{*}{50} & Halde Königsgrube & Herne & 5 & 5 & Mine tip & Park with some mine buildingrelics & yes & no \\
\hline & Halde Lohwiese & Gelsenkirchen & 14 & $?$ & Mine tip & Park with sport facilities. & yes & no \\
\hline 51 & Halde Lothringen I/II & Bochum & $16-26$ & 5 & Mine tip & $\begin{array}{l}\text { Greened over and covered with paths. Landmark built from thick } \\
\text { yellow pipes.An element of the theme trail: 'Landmarks and } \\
\text { Panorama Points' of 'Route Industriekultur'. }\end{array}$ & yes & no \\
\hline 52 & Halde Massen & $\begin{array}{l}\text { Dortmund and } \\
\text { Unna }\end{array}$ & 10 & $?$ & Mine tip & Small park. & yes & no \\
\hline 53 & Halde Maximilian & Hamm & 7,5 & 4 & Mine tip & Part of a Maximilian Park. & yes & yes \\
\hline 54 & $\begin{array}{l}\text { Halde Minister } \\
\text { Achenbach I/II }\end{array}$ & Lünen & 38 & 27 & Mine tip & Greened over and covered with paths. & yes & no \\
\hline 55 & $\begin{array}{l}\text { Halde Minister } \\
\text { Achenbach III }\end{array}$ & Lünen & 9 & 0,5 & Mine tip & Greened over and covered with paths. & yes & no \\
\hline 56 & $\begin{array}{l}\text { Halde Minister } \\
\text { Achenbach IV (Halde } \\
\text { Tockhausen) }\end{array}$ & Lünen & 36 & 12 & Mine tip & Greened over and covered with paths. & yes & no \\
\hline 57 & Möllerhalde & Gladbeck & 13 & 4 & Mine tip & Greened over and covered with paths. & yes & no \\
\hline 58 & Halde Monopol & Bergkamen & 35 & 10 & Mine tip & Completely overgrown, only minor paths for walkers. & yes & no \\
\hline 59 & Halde Monopol & Kamen & 6 & 6,5 & Mine tip & Part of a Technopark. & yes & no \\
\hline 60 & Mottbruchhalde & Gladbeck & 88 & 57 & Mine tip & $\begin{array}{l}\text { Part of the 'Braucker Alpen'. It is still growing because of material } \\
\text { deposited there, so is inaccessible. }\end{array}$ & no & inaccessible \\
\hline 61 & Halde & Neukirchen- & 74 & 90 & Mine tip & Recreational area with a steel framed house which is reminiscent of a & yes & no \\
\hline
\end{tabular}




\begin{tabular}{|c|c|c|c|c|c|c|c|c|}
\hline & Norddeutschland & Vluyn & & & & $\begin{array}{l}\text { large greenhouse in the garden. The wind can blow freely through } \\
\text { the steel beams and 'whistle'. An element of the theme trail: } \\
\text { 'Landmarks and Panorama Points' of 'Route Industriekultur'. }\end{array}$ & & \\
\hline 62 & Halde Nordstern & Gelsenkirchen & 15 & 4 & Mine tip & Part of the NordsternLandscape Park. A viewing point. & yes & no \\
\hline 63 & Halde Oberscholven & Gelsenkirchen & 137 & 60 & Mine tip & $\begin{array}{l}\text { Greened over and covered with paths. A viewing point, wind park } \\
\text { and a big cross - place of devotions in Mai. }\end{array}$ & yes & no \\
\hline 64 & Halde Oestrum & Homberg & 14 & 14 & Mine tip & Greened over and covered with paths. & yes & no \\
\hline 65 & Halde Orion & Witten & $?$ & $?$ & Mine tip & Part of a tourist trail through Mutten Valley. & yes & yes \\
\hline 66 & Halde Pattberg & Moers & 64 & 34 & Mine tip & $\begin{array}{l}\text { Greened over and covered with paths. A viewing point and a cross at } \\
\text { the peak. Panorama point on the 'Route Industriekultur' trail and an } \\
\text { element of the theme trail: 'Landmarks and Panorama Points'. }\end{array}$ & yes & no \\
\hline 67 & $\begin{array}{l}\text { Halde Pluto-Thies } \\
\text { (Dürerhalde) }\end{array}$ & Herne & 34 & 2 & Mine tip & Greened over and covered with paths. A viewing point. & yes & no \\
\hline 68 & $\begin{array}{l}\text { Phoenix Ost } \\
\text { (Kaiserberg) }\end{array}$ & Dortmund & $?$ & 4,5 & $\begin{array}{l}\text { Ground } \\
\text { landfill }\end{array}$ & Arose during creation of Phoenix-See, is now a viewing point. & yes & no \\
\hline 69 & Halde Pluto-Wilhelm & Herne & 39 & 12,5 & Mine tip & Natural protected area, inaccessible. & no & inaccessible \\
\hline 70 & Preußenhalde & Lünen & 25 & $?$ & Mine tip & Greened over and covered with paths. & yes & no \\
\hline 71 & $\begin{array}{l}\text { Halde Prinz von } \\
\text { Preußen }\end{array}$ & Bochum & $?$ & $?$ & Mine tip & Private propertyof Bochum Environmental Services, inaccessible. & no & inaccessible \\
\hline 72 & $\begin{array}{l}\text { Halde Prosperstraße } \\
\text { (Alpincenterhalde) }\end{array}$ & Bottrop & 60 & 30 & Mine tip & $\begin{array}{l}\text { Indoor - ski slope, summer toboggan run, high rope climbing, } \\
\text { skydiving facility. }\end{array}$ & yes & yes \\
\hline 73 & Halde Radbod & Bockum & 30 & 25,5 & Mine tip & Greened over and covered with paths. & yes & no \\
\hline 74 & $\begin{array}{l}\text { Halde Recklinghausen } \\
\text { II }\end{array}$ & Recklinghausen & 10 & 5 & Mine tip & Training mine. & no & inaccessible \\
\hline 75 & Halde Rheinbaben & Gladbeck & 21 & 22 & Mine tip & Forested natural protected area, accessible. & yes & no \\
\hline 76 & Halde Rheinelbe & Gelsenkirchen & 40 & 19 & Mine tip & $\begin{array}{l}\text { Greened over and covered with paths. Landmark 'Stairway to } \\
\text { heaven'. Panorama point on the trail 'Route Industriekultur' and an } \\
\text { element of the theme trail: 'Landmarks and Panorama Points'. }\end{array}$ & yes & no \\
\hline 77 & $\begin{array}{l}\text { Halde Rheinelbe } \\
\text { (Nord) }\end{array}$ & Gelsenkirchen & 26 & 9 & Mine tip & Greened over and covered with paths. A sculpture forest. & yes & no \\
\hline 78 & Halde Rheinpreußen & Moers & 78 & 52 & Mine tip & $\begin{array}{l}\text { Landmark - a huge } 30 \mathrm{~m} \text { high red mining lamp. Panorama point on } \\
\text { the 'Route Industriekultur' trail and an element of the theme trail: } \\
\text { 'Landmarks and Panorama Points'. }\end{array}$ & yes & no \\
\hline 79 & Halde Robert Müser & Bochum & 9 & $?$ & Mine tip & Completely overgrown and offers only minor paths for walkers. & yes & no \\
\hline 80 & Halde Rockelsberg & Duisburg & 38 & 11 & Slag heap & Greened over and covered with paths. & yes & no \\
\hline 81 & Halde Roland & Oberhausen & 6 & $?$ & Mine tip & A park. & yes & no \\
\hline 82 & Ruhrgashalde & Gelsenkirchen & 6,5 & 2,5 & Mine tip & Part of a landscape park, a viewpoint. & yes & no \\
\hline 83 & Halde Rungenberg & Gelsenkirchen & 60 & 56 & Mine tip & $\begin{array}{l}\text { Landmark - a tip divided into two parts of a pyramid with a } \\
\text { headlamp on top of each. Panorama point on the 'Route } \\
\text { Industriekultur' trail and an element of the theme trail: 'Landmarks }\end{array}$ & yes & no \\
\hline
\end{tabular}




\begin{tabular}{|c|c|c|c|c|c|c|c|c|}
\hline & & & & & & and Panorama Points'. & & \\
\hline 84 & Halde Sachsen & Hamm & 32 & 10 & Mine tip & $\begin{array}{l}\text { Greened over and covered with paths. Landmarks - high cross and } \\
\text { wind-gauge. An element of the theme trail: 'Landmarks and } \\
\text { Panorama Points' of 'Route Industriekultur'. }\end{array}$ & yes & no \\
\hline 85 & Halde Schallacker & Dortmund & 20 & 5 & Slag heap & A part of Phoenix-West revitalized area, local recreational facility. & yes & no \\
\hline 86 & Halde Schleswig & Dortmund & 48 & 30 & $\begin{array}{l}\text { Mine tip, slag } \\
\text { heap }\end{array}$ & Greened over and covered with paths. & yes & no \\
\hline 87 & Halde Schöttelheide & Oberhausen & $?$ & 60 & Mine tip & Is still growing because of material deposited there, so is inaccessible. & no & inaccessible \\
\hline 88 & Halde Schurenbach & $\begin{array}{l}\text { Essen and } \\
\text { Gelsenkirchen }\end{array}$ & 50 & 50 & Mine tip & $\begin{array}{l}\text { Greened over with walking paths, mounds and a landmark - a } 15 \mathrm{~m} \\
\text { high steel slab. Used by kiteboard riders. Panorama point on the } \\
\text { 'Route Industriekultur' trail and an element of the theme trail: } \\
\text { 'Landmarks and Panorama Points'. }\end{array}$ & yes & no \\
\hline 89 & Halde Schwerin & Castrop-Rauxel & 33 & 14,5 & Mine tip & $\begin{array}{l}\text { Greened over and covered with paths. A sundial on the top - } \\
\text { landmark. Panorama point on the 'Route Industriekultur' trail, a part } \\
\text { of the theme trail: 'Landmarks and Panorama Points'. }\end{array}$ & yes & no \\
\hline 90 & Sundernrücken & Hamm & 50 & 38 & Mine tip & Currently redeveloped, inaccessible. & no & inaccessible \\
\hline 91 & Halde Unser Fritz I/IV & Gelsenkirchen & 10 & 6 & Mine tip & A part of a bicycle ore railway path. & yes & no \\
\hline 92 & $\begin{array}{l}\text { Halde Vereinigte } \\
\text { Hermann }\end{array}$ & Witten & $<5$ & $<0,5$ & Mine tip & Part of a tourist trail through Mutten Valley. & yes & yes \\
\hline 93 & $\begin{array}{l}\text { Halde Victoria I/II } \\
\text { (West) }\end{array}$ & Lünen & 25 & 4,5 & Mine tip & Greened over and covered with paths. & yes & no \\
\hline 94 & $\begin{array}{l}\text { Halde Victoria I/II } \\
\text { (Ost) }\end{array}$ & Lünen & 31 & 5,5 & Mine tip & Greened over and covered with paths. & yes & no \\
\hline 95 & Halde Victoria III/IV & Lünen & 24 & 15 & Mine tip & Greened over and covered with paths. & yes & no \\
\hline 96 & Halde Voßnacken & Herne & 3 & $?$ & Mine tip & Natural protected area, inaccessible. & no & inaccessible \\
\hline 97 & $\begin{array}{l}\text { Halde Welheimer } \\
\text { Mark }\end{array}$ & Bottrop & 21 & 8 & Mine tip & A sports field. & yes & no \\
\hline 98 & Halde Werne III & Unna & 13 & $?$ & Mine tip & Greened over and covered with paths. & yes & no \\
\hline 99 & $\begin{array}{l}\text { Halde Wilhelmine } \\
\text { Victoria II/III }\end{array}$ & Gelsenkirchen & 18 & 4 & Mine tip & Housing development. & no & no \\
\hline 100 & $\begin{array}{l}\text { Halde Zollverein } \\
\text { IV/V/XI }\end{array}$ & Essen & 40 & 35 & Mine tip & A training area for dressage horses. & yes & no \\
\hline 101 & Halde Zollverein XII & Essen & 17 & $?$ & Mine tip & Sculpture Forest. & yes & no \\
\hline 102 & $\begin{array}{l}\text { Halde } 7 \\
\text { (Stinneshalde) }\end{array}$ & Essen & 21 & 9 & Mine tip & Part of the 'Braucker Alpen', small natural protected area, accessible. & yes & no \\
\hline 103 & Halde 19 & Gladbeck & 28 & 9,5 & Mine tip & $\begin{array}{l}\text { Part of the 'Braucker Alpen' with landmark pulley from the conveyor } \\
\text { tower. }\end{array}$ & yes & no \\
\hline 104 & Halde 22 & Gladbeck & 39 & 19 & Mine tip & Part of the 'Braucker Alpen', a local recreational area with small paths. & yes & no \\
\hline
\end{tabular}

? - undefined 
The vast majority of spoil tips in the Ruhr area are already revitalised. In the process of land reclamation they were greened over and assimilated into the rest of the landscape. Some of the smaller ones are hardly visible among the surrounding forested or overgrown areas. The larger ones stand out in the flat landscape and are used as viewing points and landmarks (Tab. 1).

89 out of 104 of the distinguished spoil tips are accessible to everyone by at least one footpath.

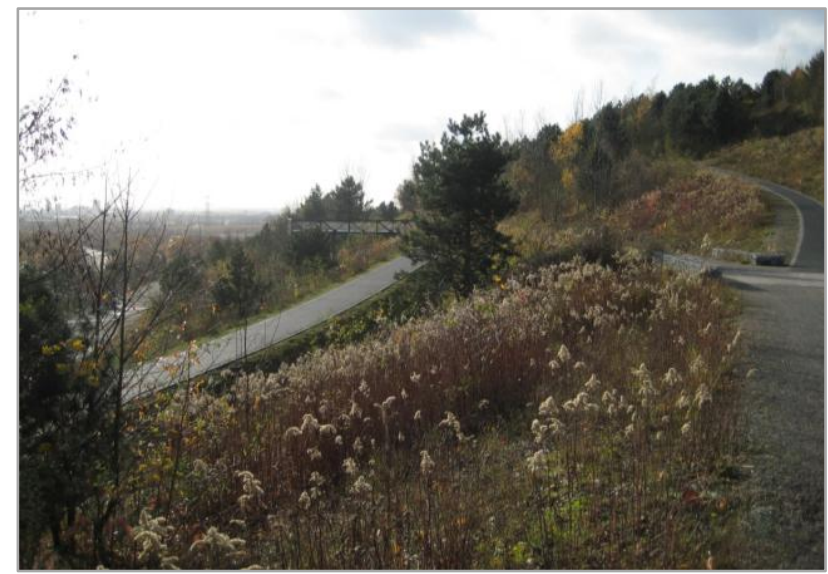

Fig. 3. Paths and viewing platform on the Hoheward tip (M. Chmielewska, 2008)

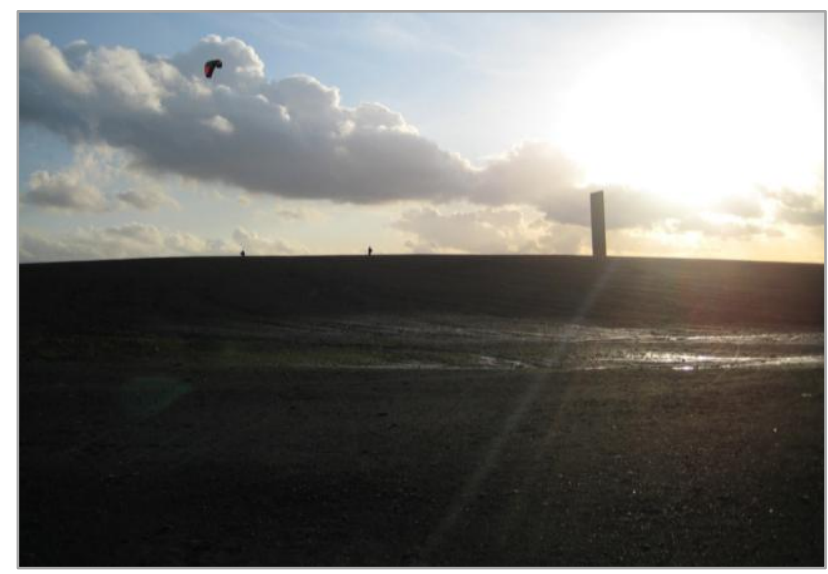

Fig. 5. The landmark at the top of the Schurenbach tip (M. Chmielewska, 2008)

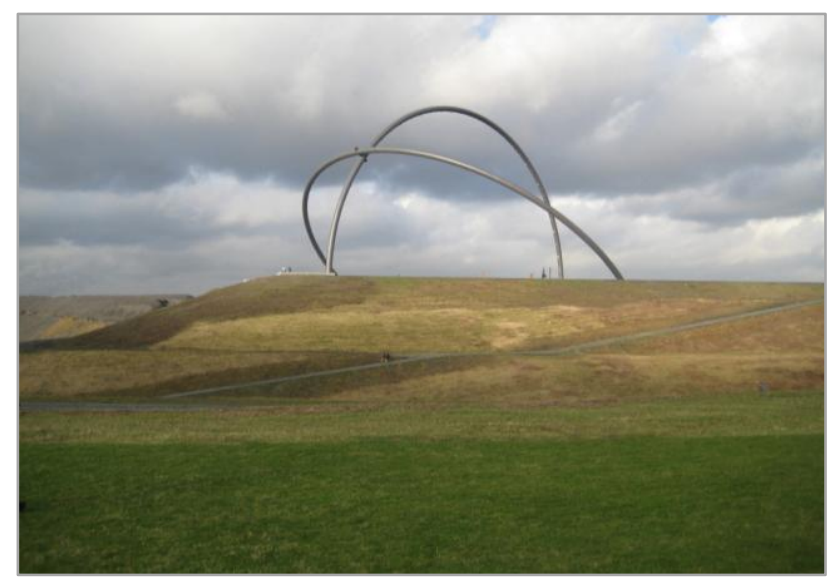

Fig. 7. The horizon observatory on the top of Hoheward tip (M. Chmielewska, 2008)
Of the 15 inaccessible spoil tips: 5 are still increasing as dumping places, 2 are currently being redeveloped, 4 are on private property, 2 are within nature protection areas, 1 is a burning tip and another 1 is a training mine. 2 former spoil tips which are accessible but without leisure possibilities have been developed into housing estates. The remaining 87 spoil tips are used for leisure and recreational areas (Tab. 1).

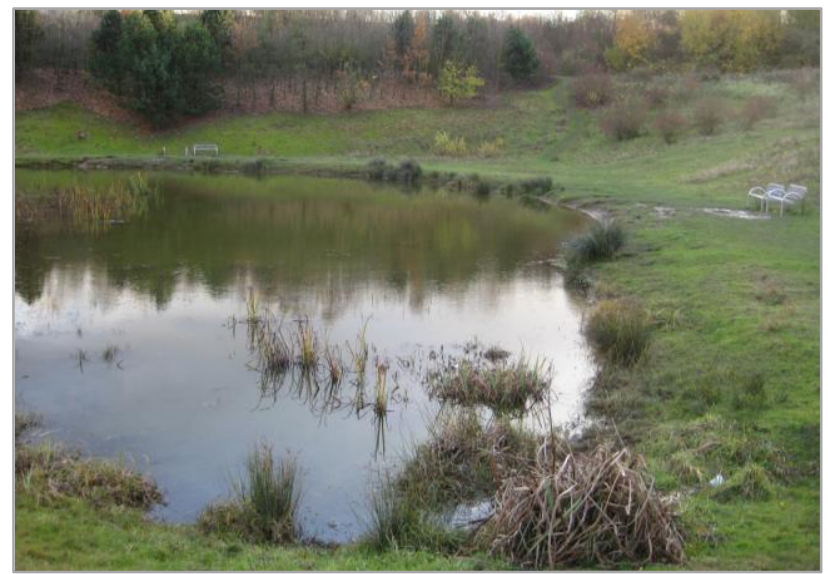

Fig. 4. Banks around the pond on the Schurenbach tip (M. Chmielewska, 2008)

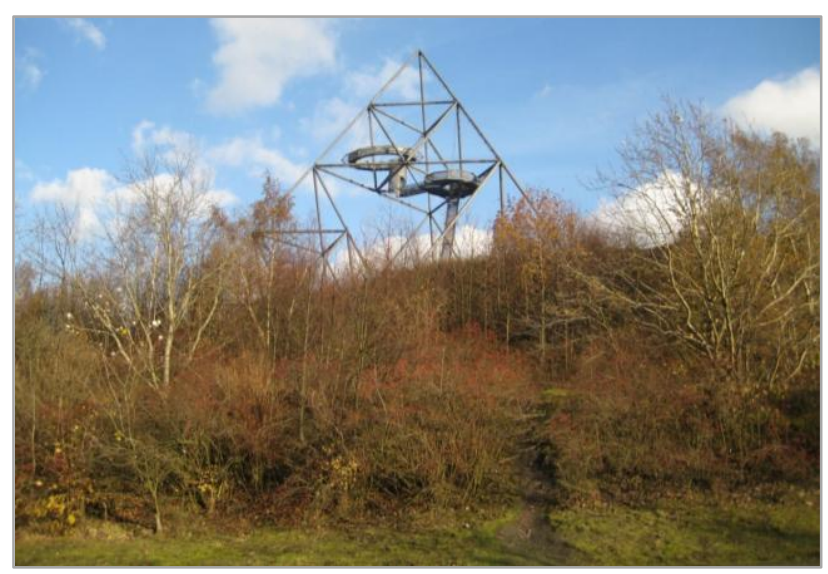

Fig. 6. Tetraeder on Bottrop (M. Chmielewska, 2008)

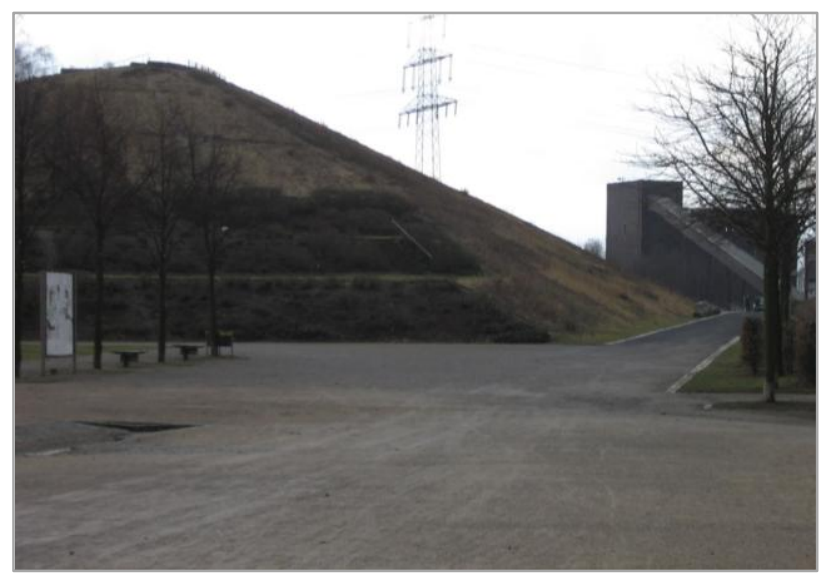

Fig. 8. A mine spoil tip in Nordstern Landscape Park (M. Chmielewska, 2006) 
The recreational functions of spoil tips are diverse, but all 87 mentioned above have at least one recreational use - they serve mainly as a place for walks (Fig. 2, 3). In addition, some of them have been changed into recreation parks with an appropriate infrastructure such as banks (Fig. 4) or playgrounds, others are used as sports facilities for skiing, sledding, kite boarding, biking, motocross racing etc. Over a dozen of the tips in the Ruhr area are tourist attractions recommended by the post-industrial heritage tourist trail in the region - "Route der Industriekultur" with great panorama points and/or landmarks (Fig. 1, 5-7). Some form parts of other tourist trails: "History of mining trail" in Bochum and "Early mining trail in Mutten Valley" in Witten. Several mine tips are connected with landscape parks: 3 form a part of the Nordstern Landscape Park (Fig. 8) and another 2 are part of the Landscape Park of Hoheward (Fig. 3, 7), some others are known as the Braucker Alps and are in a hiking area (Tab. 1).

The vast majority of the spoil tips in the Ruhr area are accessible free of charge, even as tourist attractions. Those spoil tips located on the Alpine center halde in Bottrop require and entrance fee, as does the Maximilian Park - the location of Halde Maximilian, and the Mutten Valley which forms part of the GeoPark in the Ruhr area (Tab. 1).

In conclusion, this research has shown that is has been possible to use the majority of the spoil tips in the Ruhr area as leisure facilities after their revitalisation. Because of the direction of the implemented redevelopments and due to their free accessibility they serve a wide range of people - from locals to visitors, from children to senior citizen etc., regardless of their income. As such they mitigate the negative phenomena of socio-economic polarisation and social exclusion in the region.

\section{Discussion}

It is remarkable that most revitalisation projects implemented in Germany, incorporate the creation of leisure and recreation spaces at least as a subgoal (cf. PRosseK ET AL., 2009). This is especially noticeable in the Ruhr area which has experienced over fifty years of restructuring of its industries and the implementation of many diverse revitalisation projects and has developed into a post-modern recreational paradise (REUBER \& KRAJEWSKI, 2009).

The Ruhr region is known for numerous major revitalisation projects which have led to the creation of large-scale leisure and entertainment spaces. The best example of these is the "Neue
Mitte" in Oberhausen which has been changed from a former steelworks area into a new city centre with a shopping mall, event halls, museums, sports facilities and amusement centre (CHMIELEWSKA \& ОTто, 2013). It is an attractive place for both locals and visitors, but not everybody can afford to visit facilities located there. The same situation applies to other new objects which are appearing in the urban spaces of the region like multiplex cinemas, musical theatres, adventure pools, aqua parks, aquaria, amusement parks, theme parks, zoos, indoor ski slopes, etc.

The entrance fees, irrespective of their economic justification, are a barrier for low-income households to participate in recreational activities and therefore reinforces the polarisation trends in the leisure sector. The prices of new recreational paradises can usually not be financed within tight budgets. For example a day in the Alpine Centre costs over 100 euros for a family with two children and at the Sea Life Centre a family of four will pay 72 euros (excluding the travelling costs). The museum facilities, which account for a significant focus of the industrial revitalisation in the Ruhr, have a different price structure,. However, they are significantly cheaper than the postmodern leisure facilities and quite often also offer special rates for recipients of transfer payments. The entrance fee for the mining museum starts at 14 euros for families and the current exhibition in the Gasometer costs 20 euros. The large enclosed parks are significantly cheaper. One example is the Maximilian Park in Hamm, situated on a former colliery site, which has a wide infrastructure especially aimed at children and which has created space for various events. Here the admission is 10 euros for a family per day (ОTто \& CHMieleWSKA, 2014).

Since the mere existence of entrance fees can discourage participation, it is very welcome for the developers of the Ruhr area to implement revitalisation projects which offer recreational opportunities that are not associated with any costs.A good example of a successful combination of an industrial monument and an everyday recreational area is the Landscape Park DuisburgNord which provides recreation opportunities for different kinds of people and is accessible to everybody free of charge (OTTO \& CHMIELEWSKA, 2012). In a similar way is functioning the Landscape Park Nordstern in Gelsenkirchen in the vicinity of the River Emscher and the Rhine - Herne Channel built in place of a coal mine with attractions like: an open-air amphitheatre on the channel bank, mock mining gallery or climbing garden (CHMIELEWSKA, 2010b). 
As shown by the research, the majority of the spoil tips in the Ruhr area are without entrance fees and therefore available to everyone.. As green areas, freely accessible parks and other recreational facilities that offer space for diverse sport activities they are important every day recreational urban spaces and as tourist sites they are attractive for visitors as well. Particularly interesting and also available free of charge is the Landscape Park Hoheward on the border of Herten and Recklingausen which is entirely organized on spoil tips and covers the area of the biggest spoil tip in the region - Hoheward tip and the neighbouring Hoppenbruch tip which offers over $20 \mathrm{~km}$ of footpaths and bike paths, several viewing platforms (Fig. 3) and an Astronomical Park on the top (CHMIELEWSKA, 2010a).

Thanks to the diversity of revitalisation projects implemented in the Ruhr area their impact on socio-economic polarisation is quite well balanced. There are of course many facilities available only to wealthy inhabitants which can exacerbate negative phenomena like social exclusion. But there are also many recreation areas, like these located in place of spoil tips, which are accessible for everyone without any social segregation. The importance of these redeveloped spoil tips is that these objects are spread all over the region which means they may serve quite a wide range of people - most of whom are local inhabitants.

\section{Conclusions}

This paper discussed the issues of the revitalisation of spoil tips and their relation to socio-economic polarisation and social exclusion in the field of municipal recreational facilities using the example of the largest post-industrial region in Europe - the Ruhr area in Germany. A 104 spoil tips of different origin, size and state of preservation were identified within the research area. The directions of revitalisation of each of them were analysed as well as their potential for mitigating negative phenomena associated with socio-economic polarisation within the region such as social exclusion. The research has shown that it is possible to use the majority of the spoil tips in the Ruhr area (87 of them) as leisure facilities as they have been transformed into green areas, parks, playgrounds, locations for sports activities and tourism. Furthermore, they are accessible free of charge (with only a few exceptions) and serve a wide range of people from locals to visitors, from children to senior citizens etc., regardless of their income. As such they may mitigate the socio-economic polarisation tendencies within the region contrary to other redevelopment projects implemented there before.

\section{References}

Behr I., Billert A., Kröning W., Muzioł-Węcławowicz A. 2003. Podręcznik rewitalizacji. Zasady procedury i metody działania współczesnych procesów rewitalizacji. Warszawa.

Berke W. 2011. Überalle Berge. Der definitive Haldenführer Ruhrgebiet. Klartex Verlag, Essen.

Chmielewska M. 2010a. Park krajobrazowy Hoheward w Zagłębiu Ruhry - przykład rewitalizacji hałdy pogórniczej. Kształt. środ. geogr. i ochr. przyr. na obsz. uprzem. i zurban., 42: 14-18.

Chmielewska M. 2010b. Tourism as a way of revitalization of post-industrial landscape: the Industrial Heritage Trail in Ruhr Area (Germany). Anthropogenic aspects of landscape transformations, 6: 11-15.

Chmielewska M., Otto M. 2013. The impact of revitalization on the evolution of urban space on former iron and steel works areas in Ruhr region (Germany). Environ. \& Socioecon. Stud., 1,1: 31-37.

Colantonio A., Potter R.B. 2006. City profile Hawana. Cities, 23,1: 63-78.

Domański B. 2000. Restrukturyzacja terenów poprzemysłowych w miastach. [in:] Ziobrowski Z., Ptaszycka-Jackowska D., Rębowska A., Geissler A. (eds.) Rewitalizacja, rehabilitacja, restrukturyzacja, odnowa miast. Inst. Gosp. Przest. i Komun., Kraków.

Dorling D., Woodward R. 1996. Social Polarisation 1971-1991: A Micro-geographical Analysis of Britain. Progress in Planning, 45, 2: 63-122.

Friedrichs J., Triemer S. 2008. Gespaltene Städte? Soziale und ethnische Segregation in deutschen Großstädten. Wiesbaden.

Gale D.E. 1996. Understanding Urban Unrest: from Reverend King to Rodney King. Sage Publ., London.

Hamnett C. 1998. Social polarisation, economic restructuring and welfare state regimes. [in:] Musterd S., Ostendorf W. (eds.) Urban Segregation and the Welfare State: Inequality and Exclusion in Western Cities. Routledge, London.

Jarczewski W. 2010. Skala degradacji miast w Polsce. [in:] Ziobrowski Z., Jarczewski W. (ed.) Rewitalizacja miast polskich - diagnoza. Rewitalizacja miast polskich, 8. Inst. Rozwoju Miast, Kraków: 57-64.

Kaczmarek S. 2001. Rewitalizacja terenów poprzemysłowych. Nowy wymiar $w$ rozwoju miast. Łódź.

Knox P., Pinch S. 2000. Urban Social Geography: an Introduction. Pearson Edu. Ltd., Harlow.

Lamparska-Wieland M., Waga J.M. 2003. Znaczenie hałd poeksploatacyjnych w krajobrazie Górnego Śląska. Arch. Ochr. Środ., 29, 2:107-113.

Lange D. (ed.). 2005. Atlas der Industriekultur Ruhrgebiet. Regionalverband Ruhr, Essen.

Lorens P. 2010. Rewitalizacja miasta. Planowanie i realizacja. Polit. Gdań., Wydz. Arch., Gdańsk.

Marcus P., Van Kempen R. (eds.) 2000. Globalizing Cities, A new spatial organ. Blackwell, Oxford.

Marcus P., Van Kempen R. 2002. Of state and cities the partitioning of urban space. Oxford Geogr. and Environ. Stud., Oxford Univ. Press.

McCarthy J. 1999. Chicago: a case study of social exclusion and city regeneration. Cities, 16, 5: 323-331.

Musterd S., Ostendorf W. 1998. Segregation, polarisation and social exclusion in metropolitan areas. [in:] Musterd S., Ostendorf W. (eds.) Urban Segregation and the Welfare State: Inequality and Exclusion in Western Cities. Routledge, London. 
Otto M., Chmielewska M. 2012. Revitalisation for everybody? The Landscape Park Duisburg - North. Acta Geogr. Silesiana, 12: 27-40.

Otto M., Chmielewska M. 2014. Social Inclusion by Revitalization? The Potential of Disused Industrial Areas As an Opportunity for Mitigating Social Polarization. Quaestiones Geogr., 33(2):115-125.

Prossek A., Schneider H., Wessel H.A., Wetterau B., Wiktorin D. (ed.) 2009. Atlas der Metropole Ruhr. Vielfalt und Wandel des Ruhrgebiet simKarten bild. Köln.

Reuber P., Krajewski C. 2009. Postmoderne Freizeit - und Erlebnislandschaft. [in:] Prossek A. et al. (ed.) Atlas der Metropole Ruhr. Calbe: 180-183.
Sassen S. 1991. The global city - New York, London, Tokyo, New Jersey. Princeton Univ. Press, New York.

Scholz F. 2004. Geographische Entwicklungsforschung. Stuttgart.

Wiegandt C. 2012. Stadtentwicklung in Deutschland. Trend zur Polarisierung. Geogr. Rundschau, 64 (7-8): 46-53.

Więcławowicz G. 2007. Geografia społecznie miast. PWN, Warszawa.

www.ruhrgebiet-industriekultur.de/halden

Zepp H. 2004. Geomorphologie, Paderborn. 